$4^{\text {th }}$ International Meeting on Calcitonin Gene-Related Peptide (CGRP)

TheScientificWorld (2001) 1(S1), 46

ISSN 1532-2246; DOI 10.1100/tsw.2001.441

\title{
FUNCTIONAL CHARACTERISATION OF THE CGRP ANTAGONIST BIBN4096BS, IN SK-N-MC CELLS
}

\author{
Marcus Schindler and Henri Doods \\ Boehringer Ingelheim Pharma KG, Cardiovascular Research, 88397 Biberach, Germany
}

The 37-amino acid vasodilatory peptide calcitonin gene-related peptide (CGRP) has been implicated in the pathophysiology of migraine. We have recently developed a nonpeptide CGRP antagonist, BIBN4096BS, with subnanomolar affinity for primate CGRP-1 receptors. BIBN4096BS proved to be a valuable tool to dissect CGRP receptor pharmacology[1]. Interestingly, in functional assays in some tissue, the $\mathrm{pK}_{\mathrm{B}}$ values for BIBN4096BS differ depending on the agonist used, $\alpha$ - or $\beta$-CGRP[2]. We have therefore examined the potency of BIBN4096BS to block cyclic AMP accumulation caused by $\alpha$ - or $\beta$-CGRP, in SK-N-MC human neuroblastoma cells. We have also used a novel radioligand, ${ }^{125} \mathrm{I}-\mathrm{Tyr}^{0}-\beta$-CGRP to determine the binding affinity of BIBN4096BS to probe whether a different $\beta$-CGRP receptor binding site exists.

${ }^{125}$ I-Tyr $^{0}-\beta$-CGRP was custom synthesised by Biotrend. SK-N-MC were cultured as described[3]. Agonists $\left(10^{-4}\right.$ to $\left.10^{-11} \mathrm{M}\right)$ were given simultaneously with BIBN4096 BS (10 ${ }^{-9}$ to $10^{-}$ $14 \mathrm{M}$ ), then incubated for $30 \mathrm{~min}$ at room temperature. Cyclic AMP was measured using Flashplates (NEN). Schild Plot analysis was carried out to determine $\mathrm{pK}_{\mathrm{B}}$ values (Graph Pad Prism). Radioligand binding on SK-N-MC cell membranes was carried out as described[3]. All experiments were carried out with $n \geq 3$, in triplicate.

BIBN4096BS blocked the cAMP stimulation evoked by $\alpha$-CGRP with very high potency ( $\mathrm{pK}_{\mathrm{B}}$ 13.4). BIBN4096BS was equally effective in blocking $\beta$-CGRP effects ( $\mathrm{KK}_{\mathrm{B}}$ 13.7). The slopes for both Schild plots were not different from unity. In binding experiments, BIBN4096BS displaced ${ }^{125} \mathrm{I}_{-} \mathrm{Tyr}^{0}-\beta$-CGRP with an Ki value of 11.7 , which is not significantly different to that previously determined using ${ }^{125} \mathrm{I}-\mathrm{h}-\alpha$-CGRP.

BIBN4096BS is a highly potent full CGRP antagonist on SK-N-MC cells. The equipotency of BIBN4096BS versus $\alpha$-or $\beta$-CGRP suggest that there are no differential binding sites present in this cell line.

\section{REFERENCES}

1. $\quad$ Wu, D. et al. (2000) Eur. J. Pharmacol. 400, 313-319.

2. $\quad \mathrm{Wu}, \mathrm{D}$. et al. (2001) this meeting.

3. $\quad$ Doods, H. et al. (2000) Br. J. Pharmacol. 129, 420-423. 

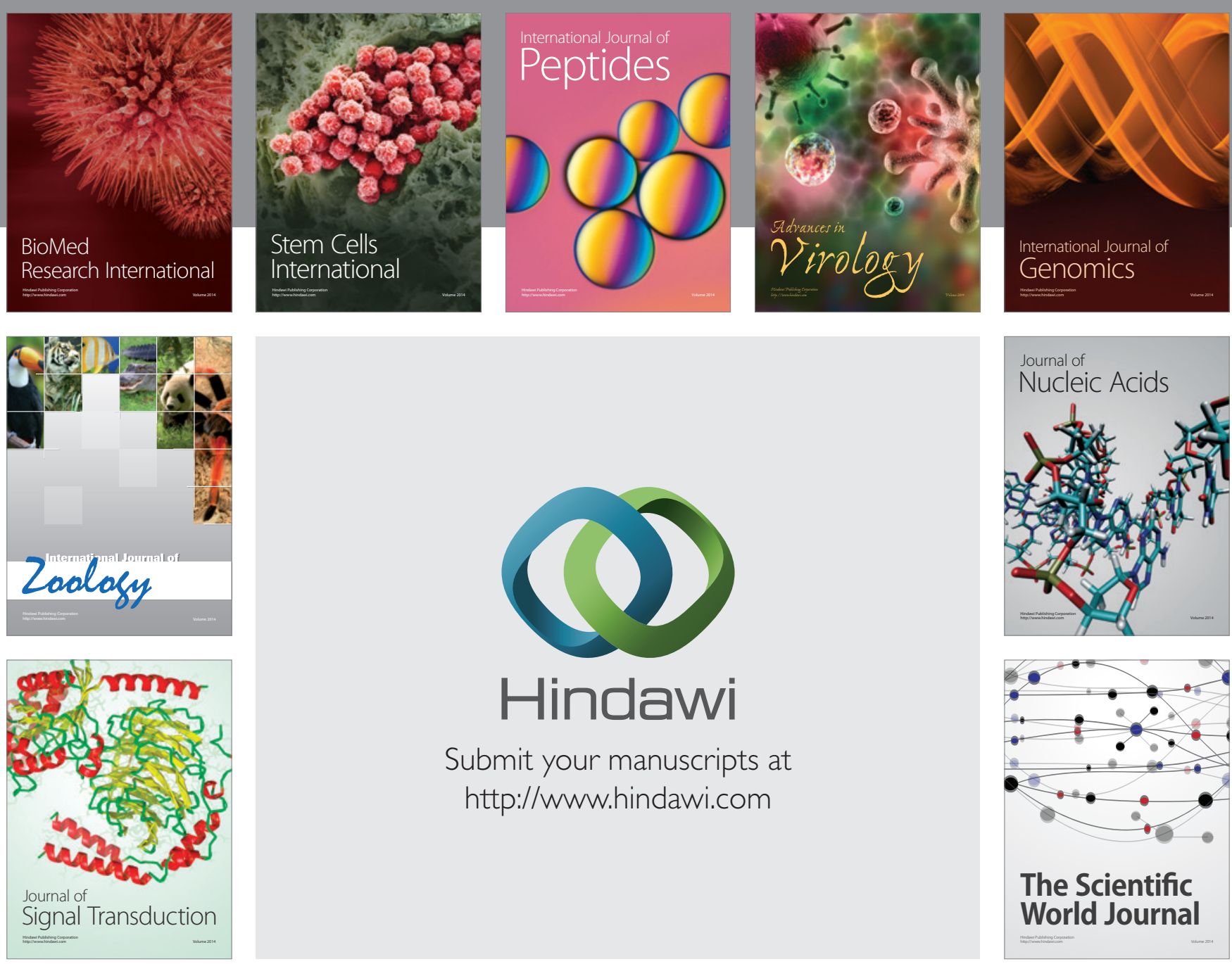

Submit your manuscripts at

http://www.hindawi.com
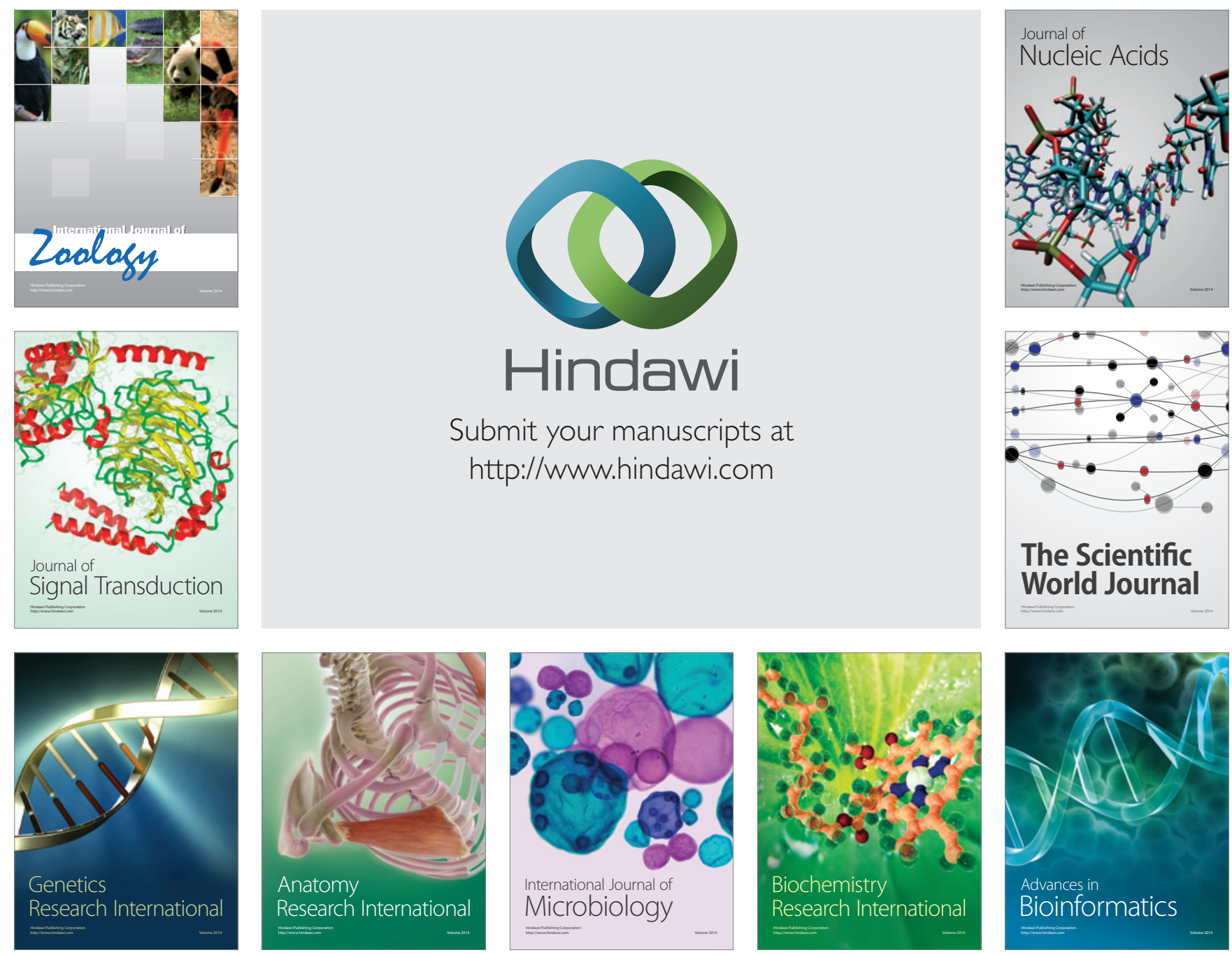

The Scientific World Journal
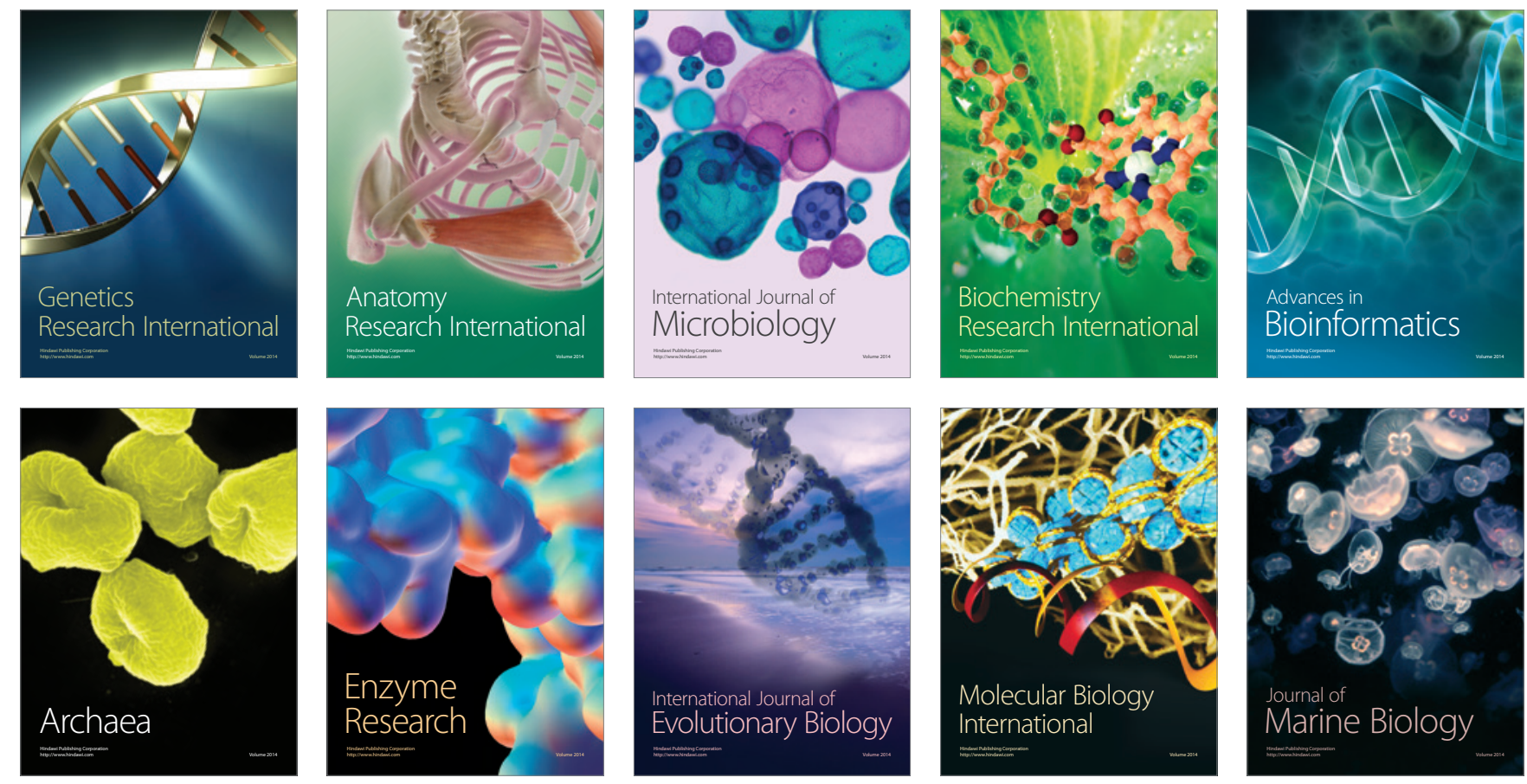